\author{
Artur Ablov \\ University of Warsaw \\ e-mail: aablov@wne.uw.edu.pl
}

\title{
THE FIRM-LEVEL AND REGIONAL DETERMINANTS OF FDI DISTRIBUTION IN POLAND: DOES SECTOR OF ECONOMY MATTER?
}

\section{WEWNĄTRZFIRMOWE I REGIONALNE DETERMINANTY PODZIALU BEZPOŚREDNICH INWESTYCJI ZAGRANICZNYCH W POLSCE: CZY SEKTOR GOSPODARKI MA ZNACZENIE?}

DOI: $10.15611 / \mathrm{e} 21.2015 .4 .05$

JEL Classification: F21, F23

Summary: This article examines the firm-level and regional determinants of inward FDI into Polish firms in the framework of sectoral analysis. All Polish companies with foreign capital (21 895 firms) were divided into three basic groups: firms of manufacturing sector (11 064 firms), services (6718) and sales (4149). This investigation includes the period from 2003 to 2012 (10 years). The main aim of this article is to determine what factors (firm-level or regional) have more impact on FDI attraction and how their impact depends on a sector which a host firm operates in. The firm-level characteristics which were used in this analysis were total assets of a host firm, its productivity, firm size, R\&D expenditure, level of high-skilled workers and age of a recipient firm. The regional determinants of inward FDI into Polish firms were: the economic potential of a region in which a firm operates, the road and rail road density of this region and the location of a firm: closer to EU or non-EU countries and closer to seaside or to the capital city - Warsaw.

Keywords: foreign direct investment, firm-level characteristics, regional determinant, location choice, Polish firms.

Streszczenie: W tym artykule omówione zostały dwa rodzaje determinant napływu bezpośrednich inwestycji zagranicznych w polskie przedsiębiorstwa w ramach analizy branżowej: determinanty regionalne $\mathrm{i}$ determinanty wewnątrzfirmowe. Wszystkie polskie firmy $\mathrm{z}$ udziałem kapitału zagranicznego były podzielone na 3 różne grupy: firmy sektora przemysłowego, firmy sektora usług oraz firmy sektora sprzedaży. Badanie to obejmuje okres od 2003 do 2012 roku (10 lat). Głównym celem niniejszego artykułu jest wyznaczenie jakie regionalne i wewnątrzfirmowe determinanty mają większy wpływ na przyciągnięcie BIZ, oraz jak ten wpływ zależy od branży, w której funkcjonuje firma przyjmująca. Analizę przeprowadzono z zastosowaniem następujących węwnątrzfirmowych determinant: łączne wartości aktywów firmy przyjmującej; wydajność firmy, koszty R\&D; liczba wysoko wykwalifikowanych pracowników oraz wiek firmy przyjmującej. Co dotyczy regionalnych 
determinant bezpośrednich inwestycji zagranicznych $\mathrm{w}$ polskie przedsiębiorstwa to zastosowane zostały: potencjał gospodarczy regionu, w którym funkcjonuje firma; gęstość drogowych i kolejowych sieci regionu oraz lokalizacji przedsiębiorstwa (odległość do granicy z krajami należącymi do UE; odległość do granicy z krajami spoza UE; odległość do morza albo stolicy Polski).

Slowa kluczowe: bezpośrednie inwestycje zagraniczne, wewnątrzfirmowe determinanty, regionalne determinanty, wybór lokalizacji, polskie przedsiębiorstwa.

\section{Introduction}

The permanent process of deepening globalization and integration provide increase in the weight of external factors, which, in turn, are the main determinants of future macroeconomic development vector of the total system of international economic relations. The important external factor which influences the economic system of countries is FDI. The role of foreign direct investment in the global economy is growing steadily. Since the mid 1980s, world FDI has been growing faster than world trade, world output and world gross domestic product (GDP).

The inflow of foreign capital into the host country impacts the competitiveness of the recipient economy and can stimulate the socio-economic development of a host country. One of the economic problems of developing and transition countries is that they do not have enough national savings to finance their investments. They are in the constant need of foreign capital in forms of both direct and indirect investments. Initially, they took loans from international commercial banks. However, in the 1980s the drying-up of commercial bank lending, because of debt crises, forced many countries to reform their investment policies so as to attract more stable forms of foreign capital, and FDI appeared to be one of the easiest way to get foreign capital without undertaking any risks linked to the debt. Thus, it became an attractive alternative to bank loans as a source of capital inflows.

Nowadays, most countries try to attract foreign capital. They especially need capital in form of foreign direct investment. Thus, there is a question how to attract FDI and what the main determinants of FDI are, what factors have more impact on the attraction of foreign investors and motivate their decision to locate production facilities or another business activity in an appropriate country: macro-level characteristics, micro-level determinants or regional factors.

The main goal of this article is to analyze how and to what extent firm-level and regional determinants impact the attraction of foreign direct investment in Polish economic system and determine what kind of factors are more influential in this case. In other words, what mostly determines FDI and motivates foreign investors to engage into foreign investment activity - micro-level factors of recipient firms or their regional characteristics. 
In addition, this article includes the sectoral analysis, which aimed to find out the significance of firm-level and regional FDI determinants for different sectors of Polish economy. There are three main sectors of economy which were chosen for this investigation: manufacture, sales and services.

There are several reasons why Poland was chosen for this analysis. Poland faced the collapse of the socialist system and passed a long and difficult path from the transition period to EU membership. Foreign direct investment became a helpful catalyst for the development of Polish socio-economic system during this period. At the same time FDI helped Poland to modernize its industrial base and adopt its economic system to European standards, which allow Poland to integrate into the European Union.

It should be mentioned that during the whole period of the analysis (2003-2012) Poland was one of the leading countries in Eastern Europe in the context of FDI attracting. It should also be noted that Poland was one of the countries that were least affected by the global financial and economic crisis and even during this crisis the inflow of FDI into Poland remained at a high level.

\section{Theoretical background}

There are a large number of studies on the topic of FDI determinants. However, all of them can be divided into three main groups. The first group includes the studies about traditional determinants of foreign direct investment such as GDP, population, openness of host economy, institutional development, etc.

The second group consists of papers which are devoted to the regional determinants of foreign direct investment, such as regional GDP, physical infrastructure, road and railway density, availability of airports and seaports, border effects, etc.

The third group includes studies of firm-level determinants of FDI inflow, such as firm size, number of employees, financial and intangible assets, the availability of high-skilled labor force, the level of productivity, age of company, etc.

The studies of traditional FDI determinants were the fundamental base for further investigations in this sphere and there was a lot of research which had an impact on this development [Resmini 1999; Bevan, Estrin 2000; Garibaldi et al. 2001; Biswas 2002; Kinoshita, Campos 2003; Carstensen, Toubal 2004; Disdier, Mayer 2004].

Since the beginning of the 2000s the theoretical background of FDI determinants obtained a new direction of research. Many authors began to analyze the regional determinants of FDI to investigate how regional characteristics influenced the attraction of investment in different regions of host economy [Broadman, Recanatini 2001; Deichmann 2002; Barrios, Strobl, Gorg 2003; Domański 2004; Cieślik 2005a; 2005b; 2005c; Boudier-Bensebaa 2005; Iwasaki, Suganuma 2005; Spilkova 2007; Basile, Castellani, Zanfei 2008; Chidlow, Salciuviene, Young 2009; Yavan 2010; Hilber, Voicu 2010; Gauselmann, Marek 2012; Cieślik 2013; Schäffler, Hecht, Moritz 2014]. 
As it was mentioned above, the first two groups of research were connected with the investigations of traditional and regional FDI determinants. However, for the last five years the number of studies which are devoted to firm-level determinants of FDI have increased. Such an analysis became possible owing to a wider access to firm-level statistic data. The attempts to investigate firm-level determinants were taken even in the 70s, but due to the lack of necessary information, most of them had only theoretical assumptions. For example, in his research Horst [1972] analyzed firm and industry determinants concerning to the decision to invest abroad. He provided some empirical results, but his investigation included a small part of firm-level characteristics because its availability was strictly limited. Blomstrom and Lipsey [1991] also tried to concentrate on some firm-level determinants of foreign direct investment. In their model they included a determinant of firm size and analyzed how it influenced foreign operation of multinational enterprises.

At the same time with the development of theoretical background of FDI determinants, also the availability of statistical data increased. Modern statistical reports allowed authors to analyze deeply how firm-level characteristics influenced FDI attraction. This direction is nowadays very popular and supported by many scholars [Pusterla, Resmini 2007; Basile, Castellani, Zanfei 2008; Kasuga 2007; Raff, Ryan 2008; Görg, Mühlen, Nunnenkamp 2010a; 2010b; Kinda 2010; Gauselmann, Knell, Stephan 2011; Liu, Nunnenkamp 2011; Wang, Alba, Park 2013; Xu, Sheng 2012; Amendolagine et al. 2013; Gauselmann, Marek 2012; Cieślik 2013; Cieślik, Michałek, Nasadiuk 2015].

As it was mentioned above such evolution of theoretical background in the sphere of FDI determinants was connected with the development of statistical data for regions rather than for firms. It allowed research to investigate the determinants of FDI in more details considering special regional characteristics and than the features of firm-level factors.

This evolution can be regarded as a deduction in philosophy. For the last decades, the investigators have gone through a great path from the analysis of aggregated factors (such as GDP, unemployment, openness of host economy and their impact on FDI attractiveness) to the comprehensive analysis of the mechanism for FDI attraction on the micro level (this direction covers the analysis of such determinants as firm-size, assets of a company, firm's age, R\&D expenditure, the number of highskilled workers, etc.) and how this mechanism operates in every special area (for example region of country) (this direction includes the investigation of such determinants as market-size of a region and its potential, agglomeration, road and railway density, border effects, etc.).

It should be noticed that the last tendency in the sphere of research on FDI determinants is the combination of two approaches: firm-level and regional. Nowadays we can observe the process of integration and increasing the interdependence between all approaches, but the effective mechanism of its combination 
is undeveloped now. There are only few studies devoted to this direction [Gauselmann, Marek 2012; Cieślik 2013]. Therefore the creation of such a mechanism and its implementation seems to be very beneficial, and the comprehensive models, which would include the most effective set of various determinants from different approaches could provide the society with advantageous results, which could be useful, particularly in practice, for example for policy makers. Thus it is more likely that this direction will be developed by a lot of research in the future.

As to determinants of FDI into Poland there are some studies which have investigated this matter. In the framework of traditional FDI determinants research it should be highlighted the papers of Ghemawat and Kennedy [1999] and Przybylska and Malina [2000]. In these studies the authors found that market-seeking factors (economies of scale, consumers' demand) had a positive impact on FDI inflows into Poland.

Also, there are some important studies in the sphere of regional FDI determinants analysis. Domański [2004] investigated the question of local and regional embeddedness of foreign industrial investors in Poland and analyzed it from the perspective of economic and social linkages developed by foreign-owned companies. He noted that special emphasis was put on their supplier relationships as well as quantitative and qualitative impact on labor market. His study showed that the growing number of foreign investors became embedded in Polish regions and communities, at the same time making them integrated into global economy.

The next contribution to the development of theoretical background in the sphere of FDI regional determinants was provided by Andrzej Cieślik who published his trilogy of papers in 2005.

The main goal of the first article from this trilogy [Cieślik 2005a] was the empirical investigation of the different determinants of FDI that could impact the spatial distribution of foreign companies within Poland in the transition period. The second paper of trilogy investigated the border effects and their importance for the foreign firms' location within Poland. The third part of trilogy continued the previous research and was devoted to the importance of border effects for the location of multinational enterprises in Poland in case of 16 new Polish regions (voivodships). The estimation results of author's model show that regions located close to the eastern border are less attractive to foreign companies compared to their counterparts located in central and western parts of the country. Cieślik [2005c] considered that these results suggested that less attractive regions needed the development of special economic policy, which could compensate for their disadvantaged location resulting from Poland's increased integration with the European Union.

Chidlow, Salciuviene and Young [2009] continued the investigation of FDI regional determinants in Poland. Their findings confirmed that Polish regions were considerably different in the context of FDI attracting and proved that regional 
determinants had impacted the location choice of foreign companies, which decided to invest into Poland.

One of the most important studies which gave a new direction of investigation in the sphere of firm-level FDI determinants was the study of Pusterla and Resmini [2007]. The authors used in this paper the firm-level datasets on foreign manufacturing plants in 4 CEE states (Hungary, Bulgaria, Romania and Poland) to analyze their location and to estimate the determinants which affected the choice processes. In their study Pusterla and Resmini [2007] verified and confirmed that agglomeration forces were important determinants of FDI. They also stated that the probability that foreign company would locate their FDI into transition economies was mainly influenced by demand determinants rather than cost factors.

Gauselmann, Knell and Stephan [2011] in their article were focused on the dependence between locational advantages offered by CEE countries and strategic motives of foreign investors in these countries. Their analysis included such firmlevel determinants of FDI location as potential for knowledge spillovers and technological activity of subsidiaries in Hungary, the Czech Republic, Romania, Slovakia and Poland.

Their results suggested that investors in CEE countries were primarily interested in educated and high-skilled workforce as well as low labor costs. They also emphasized the importance of such a determinant as an expanding market of the recipient country and increasing level of the potential buyers' purchasing power. Moreover, the authors showed that such a determinant as financial crisis reduced the investment attractiveness of the CEE region in most cases.

As it was mentioned above, the latest tendency in the investigation of FDI determinants is the combining of regional and firm-level factors. Now there is a very limited number of such research. The most important studies in this field were provided by Gauselmann and Marek [2012] and Cieślik [2013].

The paper of Gauselmann and Marek [2012] focused on the impact of such determinants as labor market and agglomeration on the MNCs' location choice in post-transition countries. They compared datasets from 33 different regions in the Czech Republic, East Germany and Poland using in their model firm-level data.

The results of the authors showed considerable and positive influence of such determinants as potential for knowledge spillovers and specialization in the sector on the decision of location choice in post-transition regions. They noted that their model showed no differences in the influence on MNC location choice by such a determinant as agglomeration economies in all analyzed post-transition regions. Their results proved that among the most important location factors for investors in post-transition regions were technological performance of the target region and sectoral specialization.

The authors proved that labor market factors had affected the location choice of FDI in post-transition countries but in contradistinction to existing research in the 
sphere of location choice in Central and Eastern European countries [Cieślik 2005; Pusterla, Resmini 2007] - in line with Hilber and Voicu [2010] who indicated that higher wages did not distract investors.

Cieślik [2013] added firm-level FDI determinants to his previous research on this topic [Cieślik 2005a; 2005b; 2005c]. The main idea of his study was the investigation of the determinants which affected foreign companies' location in Polish regions and in contrast to other studies in this sphere he paid a lot attention and focused specially on the role of such a determinant as firm size. The author used an analytical framework that combined the new economic geography and the firm heterogeneity literatures to prove his hypotheses on the firm location choice.

The author found that significant heterogeneity among different types of foreign firms existed with respect to the location determinants. He noted that the location of bigger firms was better explained by the set of explanatory variables than the location of smaller firms where an arbitrary component was more important. In contrast to his previous studies the estimated parameter on wages was positive and statistically significant. The author mentioned that increasing factor costs in the regions that hosted the most foreign firms should not be expected but should lead to even more distribution of foreign activity as the advantages of skilled labor and agglomeration economies in firm location decisions would remain strong.

\section{Methodology and estimation strategy}

The estimation strategy of this study consists of several stages. At the first stage, there will be presented the OLS (ordinary least squares) regression model. At the second stage of current analysis it will be conducted panel data analysis using fixed and random effects models. At the third stage there will be the comparison between the above models using the Hausman test.

1) OLS regression model. Given a data $\operatorname{set}\left\{y_{i}, x_{i 1} \ldots, x_{\dot{p}}\right\}_{i=1}^{n}$ of $n$ statistical units, a linear regression model assumes that the relationship between the dependent variable $y_{i}$ and the $p$-vector of regressors $x_{i}$ is linear. This relationship is modeled through a disturbance term or error variable $\varepsilon_{i}-$ an unobserved random variable that adds noise to the linear relationship between the dependent variable and regressors [Luo 2013]. Thus the model takes the form:

$$
y_{i}=\beta_{1} x_{i 1}+\ldots+\beta_{p} x_{i p}+\varepsilon_{i}=x_{i}^{T} \beta+\varepsilon_{i} \quad i=1, \ldots, n,
$$

where ${ }^{T}$ denotes the transpose, so that $x_{i}^{T} \beta$ is the inner product between vectors $x_{i}$ and $\beta$.

Often these $\mathrm{n}$ equations are stacked together and written in vector form as:

$$
Y=X \beta+\varepsilon,
$$


where

$$
y=\left(\begin{array}{c}
y_{1} \\
y_{2} \\
\vdots \\
y_{n}
\end{array}\right), X=\left(\begin{array}{c}
X_{1}^{T} \\
X_{2}^{T} \\
\vdots \\
X_{n}^{T}
\end{array}\right)=\left(\begin{array}{ccc}
x_{11} & \cdots & x_{1 p} \\
x_{21} & \cdots & x_{2 p} \\
\vdots & \ddots & \vdots \\
x_{n 1} & \cdots & x_{n p}
\end{array}\right), \beta=\left(\begin{array}{c}
\beta_{1} \\
\beta_{2} \\
\vdots \\
\beta_{p}
\end{array}\right), \varepsilon=\left(\begin{array}{c}
\varepsilon_{1} \\
\varepsilon_{2} \\
\vdots \\
\varepsilon_{n}
\end{array}\right)
$$

$y \quad-$ is the depended variable, in case of this model - FDI $-\ln$ (FDI).

$X_{1}^{T} \ldots X_{n}^{T}$-are independent variables: logarithm of total assets of firm-ln(ASSET), logarithm of productivity $-\ln (\mathrm{PROD})$, logarithm of R\&D - $\ln (\mathrm{RD})$, logarithm of firm size $-\ln (\mathrm{FS})$, level of high-skilled workers - $\ln$ (HSW), logarithm of firm's age $-\ln (\mathrm{AGE})$, logarithm of economic potential of region in which operates a firm $-\ln (E P R)$, road $-\ln ($ ROAD) and railroad density $-\ln ($ RAIL), location of a firm $-\ln (\mathrm{LOC})$.

$\beta-$ is a $p$-dimensional parameter vector. Its elements are also called effects, or regression coefficients. Statistical estimation and inference in linear regression focuses on $\beta$. The elements of this parameter vector are interpreted as the partial derivatives of the dependent variable with respect to the various independent variables.

$\varepsilon_{i} \quad-$ is called the error term, disturbance term, or noise. This variable captures all other factors which influence the dependent variable $y_{i}$ other than the regressors $x_{i}$. The relationship between the error term and the regressors, for example whether they are correlated, is a crucial step in formulating a linear regression model, as it will determine the method used for estimation.

In the framework of current analysis the equation of linear regression in this model is:

$$
\begin{gathered}
\ln (F D I)=\beta_{1} \ln (A S S E T)+\beta_{2} \ln (P R O D)+\beta_{3} \ln (R D)+\beta_{4} \ln (F S)+\beta_{5} H S W+ \\
+\beta_{6} \ln (A G E)+\beta_{7} \ln (E P R)+\beta_{8} R O A D+\beta_{9} R A I L+\beta_{10} L O C+\varepsilon_{10} .
\end{gathered}
$$

2) Fixed effects model. Fixed effects model explores the relationship between predictor and outcome variables within an entity (country, person, company, etc.). Each entity has its own individual characteristics that may or may not influence the predictor variables [Torres-Reyna 2007].

The equation for the fixed effects model is:

$$
Y_{i t}=\beta_{0}+\beta_{1} X_{1, i t}+\ldots+\beta_{k} X_{k, i t}+\gamma_{2} \mathrm{E}_{2}+\ldots+\gamma_{n} \mathrm{E}_{n}+\mu_{i t},
$$

where:

$Y_{i t}$ is the dependent variable $\ln (\mathrm{FDI})$ where $i=$ entity and $t=$ time.

$X_{k, i t}$ represents the independent variables: $\ln (\mathrm{ASSET}), \ln (\mathrm{PROD}), \ln (\mathrm{RD}), \ln (\mathrm{FS})$,

$\ln (\mathrm{HSW}), \ln (\mathrm{AGE}), \ln (\mathrm{EPR}), \ln (\mathrm{ROAD}), \ln (\mathrm{RAIL}), \ln (\mathrm{LOC})$.

$\beta_{k}$ is the coefficient for that independent variables.

$\mu_{i t}$ is the error term. 
$E_{n}$ is the entity $n$. Since they are binary (dummies) there are $n-1$ entities included in the model.

$\gamma_{2}$ is the coefficient for the binary repressors (entities).

The fixed effects equation for the current model is:

$$
\begin{gathered}
\ln (F D I)=\beta_{0}+\beta_{1} \ln (A S S E T)+\beta_{2} \ln (P R O D)+\beta_{3} \ln (R D)+\beta_{4} \ln (F S)+\beta_{5} H S W+ \\
+\beta_{6} \ln (A G E)+\beta_{7} \ln (E P R)+\beta_{8} R O A D+\beta_{9} R A I L+\gamma_{2} L O C_{2}+\mu_{10,10^{\circ}}
\end{gathered}
$$

3) Random effects model. The rationale behind random effects model is that, unlike the fixed effects model, the variation across entities is assumed to be random and uncorrelated with the predictor or independent variables included in the model [Torres-Reyna 2007].

The random effects model is:

$$
Y_{i t}=\beta X_{i t}+\alpha+\mu_{i t}+\varepsilon_{i t},
$$

where:

$\alpha$ is the unknown intercept for each entity ( $n$ entity-specific intercepts),

$\varepsilon_{i t}$ is within-entity error,

$\mu_{i t}$ is between-entity error.

Random effects model allows to generalize the inferences beyond the sample used in the model.

The random effects equation for the current model is:

$$
\begin{aligned}
& \ln (F D I)=\beta_{1} \ln (A S S E T)+\beta_{2} \ln (P R O D)+\beta_{3} \ln (R D)+\beta_{4} \ln (F S)+\beta_{5} H S W+ \\
& +\beta_{6} \ln (A G E)+\beta_{7} \ln (E P R)+\beta_{8} R O A D+\beta_{9} R A I L+\beta_{10} L O C+\alpha+\mu_{10,10}+\varepsilon_{10,10} .
\end{aligned}
$$

4) Hausman test. To decide between fixed or random effects a Hausman test should be run where the null hypothesis is that the preferred model is random effects vs. the alternative the fixed effects [Green 2008, chapter 9]. It basically tests whether the unique errors $\left(\mu_{i}\right)$ are correlated with the regressors. The null hypothesis indicates they are not [Torres-Reyna 2007].

\section{Data description}

There are two main sources of data used in this study. The data on Polish firms and their micro-level characteristics have been obtained from AMADEUS database provided by Bureau van Dijk. AMADEUS contains comprehensive information on around 21 million companies across Europe. This source has firm-level data of 147,878 Polish companies from all sectors of economy.

The datasets, which were obtained from AMADEUS (Bureau van Dijk) included the following characteristics: company name, NACE Rev. 2 main section, region, date of incorporation, annual operating revenue (turnover), annual total assets, 
number of employees, annual intangible assets, annual sales, number of current directors/managers, annual shareholders funds, shareholder country ISO code and shareholder direct $\%$ ( $\%$ of foreign capital).

For the current analysis there were selected Polish firms which had foreign capital and the share of foreign capital was more than $10 \%$ for each company. Additionally, all selected firms were divided into three groups according to their belonging to an appropriate sector of Polish economy: manufacture, sales or services.

After the division there were selected 21895 Polish firms with foreign capital: 11064 firms from manufacturing sector, 6718 - from the sales sector and 4149 firms from the services sector. There is an assumption that the significance of different determinants can vary depending on the sectors of economy.

The second source of dataset is the Polish Central Statistical Office (CSO) in Warsaw. The datasets which were obtained from CSO included the following characteristics: annual regional GDP of each Polish region (16 Voivodships), the area of each region (in $\mathrm{km}^{2}$ ), distances between all major cities (capital of regions), the annual road and railroad density in Poland.

All of the above datasets including data on micro-level from AMADEUS (Bureau van Dijk) and regional data from the Polish Central Statistical Office cover the period of time from 2003 to 2012 (10 years).

\section{Model specification and variables description}

\subsection{Dependent variable}

Research often represents FDI as a dependent variable in its models, but it should be mentioned that there are many ways and approaches to measuring this factor. Cieślik (2005a) for measuring of FDI used the number of firms with foreign capital participation for each region in Poland. Boudier-Bensebaa [2005] examined the determinants of FDI at a regional level in Hungary and in comparison with the study of Cieślik [2005a] he used the distribution of the FDI stocks in the county as a dependent variable. Iwasaki and Suganuma [2005] considered the foreign direct investment for each region as a dependent variable in their model.

Spilkova [2007] in her study used an approach which was different in comparison with Cieślik [2005a], Boudier-Bensebaa [2005], Iwasaki and Suganuma [2005] and others. She considered the average ratings of regions that she obtained through the questionnaire (sum of perception by foreign firms) as a dependent variable (FDI).

The approach to the definition of dependent variable (FDI) in the model of Basile, Castellani and Zanfei [2008] was very different from the previous studies on FDI determinants. The authors investigated the location choice in fifty European regions and they built such a model in which each company faced 50 possible variants (choices) and consequently the dependent variable was equal to 1 if company 
$i$ was set in region $j$ and zero for all different regions. Pusterla and Resmini [2007] used the similar approach in their study.

Raff and Ryan [2008] in their paper analyzed how firm-specific characteristics influenced foreign direct investment from Japan to European countries. They used investments of 286 Japanese manufacturing firms as a dependent variable.

Chidlow, Salciuviene and Young [2009] created a model in which the probability of either investing or not in any given region of Poland was a dependent variable. The core region in this model was Mazowieckie region.

Kinda [2010] in his paper analyzed how investment climate constraints jeopardized developing countries' attractiveness for FDI. The dependant variable (FDI) in this model took value one if at least $10 \%$ of the firm's capital was foreign (following the IMF standard of FDI definition) and zero otherwise. Such an approach was used by other authors who investigated regional determinants of FDI [Pusterla, Resmini 2007; Basile, Castellani, Zanfei 2008].

Gauselmann and Marek [2012] defined that location choice was the dependent variable of their analysis and equaled one for the region chosen by the MNC, and otherwise was zero. Such an approach was used by other researchers such as Pusterla and Resmini [2007], Basile, Castellani and Zanfei [2008] and Kinda [2010].

Amendolagine et al. [2013] in their study considered that such a determinant as local linkages was very important for FDI attracting.

The authors defined dependent variable as the cost share of local inputs, measured as the share of the cost of locally manufactured inputs in total costs and total costs were given by the sum of costs of capital, labor, local intermediate inputs, and imported intermediate inputs.

Cieślik [2013] as it was in his earlier papers measured FDI by the number of operational foreign firms in each region of Poland and used it as the dependent variable in his model.

Schäffler, Hecht and Moritz [2014] in their paper investigated the regional determinants for German investment projects in the Czech Republic for the home and the host country and the number of investments in their research was calculated as regional combinations between German spatial planning regions and Czech regions. In other words the dependent variable (FDI) in their study denoted the number of German-Czech FDI projects as a combination of having German headquarters in a certain German spatial planning region $i$ and a Czech affiliate being located in a specific Czech region $j$.

In this model it will be used another approach to measuring foreign direct investment. According to this approach, FDI in this model is considered as a multiplication between the share of foreign capital in the firm (in \%) and total shareholder capital of appropriate firm.

$$
F D I=\text { Share of foreign capital } \times \text { Shareholder capital } \text {. }
$$

It should be noted that in this model only firms with the share of foreign capital exceeding $10 \%$ will be used. 


\subsection{Independent variables}

\section{Firm-level determinants}

1) Total assets. In the last decade this factor has been increasingly used by scholars in the research devoted to firm-level determinants of FDI. Cieślik [2005b] used total assets in his model, which was focused on firm-level characteristics and its influence on FDI attraction into Polish regions.

Raff and Ryan [2008] in their research analyzed how firm-specific determinants impacted foreign direct investment from Japan to European countries using in their model such a variable as firm size measured by total assets of a company.

Liu and Nunnenkamp [2011] also concentrated on firm-level FDI determinants, but they investigated how such determinants impacted outward FDI from Taiwan using such a factor as total assets of the firm.

Wang, Alba and Park [2013] in their model used such a characteristic as total assets twice: in the variable firm profitability (ratio of the firm's profit to assets ratio) and in the variable firm size (inflation-adjusted value of the firm's assets).

Hagemejer and Tyrowicz [2012] also analyzed how firm-level determinants influenced foreign direct investment. They used in their model firm-level data, including total assets to investigate how these characteristics influenced foreign capital attraction in Polish medium and large enterprises.

2) Productivity. One of the famous studies on productivity and foreign direct investment was the paper of Caves [1974] in which he investigated FDI into Australian and Canadian firms of manufacturing sectors. The author stated that FDI stimulated the growth of productivity among the recipient firms. Therefore he considered that FDI was the determinant of productivity but some time later there appeared a lot of critical reviews on the Caves statement. The investigations of Djankov and Hoekman [2000] on the Czech Republic and Konings [2001] on Romania, Bulgaria and Poland rejected the above-mentioned statement about the impact of FDI on productivity because of it was difficult to determine the direction of causation.

The authors emphasized that there was no direct evidence that FDI inflow generated the recipient firms' productivity, but they found that productivity was the determinant of FDI and they stated that MNCs usually located their investment in high-productivity and high-income firms.

Raff and Ryan [2008] in their paper analyzed how firm-specific characteristics influenced foreign direct investment from Japan to European countries. The authors found that the greater such a determinant as firm productivity, the bigger the company's market share and therefore FDI more gainful and hence the time of investment implementation shorter at each stage of investment process. Hilber and Voicu [2010] obtained the similar results for the Czech Republic and Poland. They also emphasized that the high level of firm's productivity impacted the foreign investor's location decision and stimulated the inflow of FDI. 
Many researchers in their studies measured productivity as the ratio between turnover and number of employees in the firm [Görg, Mühlen, Nunnenkamp 2010a; 2010b; Liu, Nunnenkamp 2011]:

$$
\text { Productivity }=\frac{\text { Turnover }}{\text { Number of employees }} .
$$

3) R\&D. There are a lot of investigations about the linkages between FDI and R\&D [Cantwell 1989; Cantwell, Janne 1999; Cantwell, Piscitello 2002; 2005]. These authors called the FDI which was determined by R\&D as knowledge-seeking FDI. Cantwell [1989] stated that knowledge-seeking investments varied across locations because they depended on location-specific factors, such as the number of scientists and educated people in the area, previously established innovations, $R \& D$ intensity, the education system, and linkages between educational institutions and firms. As a result, firms may supplement their existing technologies by expanding internationally to access new knowledge.

If some host firm has unique technology (or knowledge) it can be said that this firm has firm-specific advantage. If this advantage may not be utilized by a home firm in a way of licensing or importing, then there is a situation in which the only option (for a home firm) to obtain the necessary technology or knowledge (from a host firm) is FDI. There is simple logic that R\&D activity should generate some technologies or knowledge. Therefore $\mathrm{R} \& \mathrm{D}$ expenditure should be a determinant of FDI. The above statements completely fit into the classic concept of Dunning [1988] in which he argued that motivation to exploit firm-specific advantages was one of the reasons for locating production facilities abroad.

Many researchers found the mutual interdependence between R\&D and FDI [Lin, Yeh 2003; Bénassy-Quéré, Coupet, Mayer 2005; Basile, Castellani, Zanfei 2008; Raff, Ryan 2008; Görg, Mühlen, Nunnenkamp 2010b; Liu, Nunnenkamp 2011; Cieślik 2013].

It should be mentioned that there are some approaches to measuring $R \& D$ activity. Raff and Ryan [2008] in their paper suggested that R\&D was the ratio of $R \& D$ expenditures to total sales for the fiscal year. Klimek [2009] considered R\&D in the framework of firm's intangible assets. In this model the combination of the above approaches will be used. R\&D index will be proxied by the ratio of firm's intangible assets to total sales for the fiscal year:

$$
R \& D \text { index }=\frac{\text { Intangible assets }}{\text { Total sales }} .
$$

4) Firm Size. Such a factor as firm size is also often used by researchers in their models devoted to FDI determinants [Blomstrom, Lipsey 1991; Raff, Ryan 2008; Liu, Nunnenkamp 2011; Wang, Alba, Park 2013; Cieślik 2013]. In their paper Blomstrom and Lipsey [1991] investigated only one determinant - firm size and analyzed how it impacted foreign operation of multinational enterprises. 
It should be mentioned that there are two main approaches of measuring firm size. According to the first approach firm size can be measured by total assets of the company [Raff, Ryan 2008; Wang, Alba Park 2013. The second approach assumes that firm size should be measured by the numbers of employees [Liu, Nunnenkamp 2011; Cieślik 2013].

In contrast to other studies in this sphere Cieślik [2013] paid a lot attention and made a special focus on the role of such a determinant as firm size. He also suggested that this determinant could be divided into four parts: micro-firms (1-9 workers), small firms (10-49 workers), medium-sized firms (50-249 workers), large firms (250 and more workers).

In this model it will be used the second approach and there are two reasons for it. Firstly, the determinant total assets is already used as another factor in this model. Secondly, the measuring of firm size by the number of employees is a more modern approach.

5) High-skilled workers. Such a determinant as high-skilled workers implies the labor force quality. It can be a very substantial factor in the process of FDI attracting especially for foreign investors who are interested in the establishment of business activities that call for a high level of human capital. Access to high-skilled labor can be the main reason for a foreign company to locate its production facilities abroad.

There are some empirical evidence that in many economies (including transition countries) there is a significant and positive interdependence between high-skilled labor force and FDI inflows [Nelson, Phelps 1966; Schneider, Frey 1985; Domański 2001; Carstensen, Toubal 2004; Hong, Li, Sun 2007; Demirhan, Masca 2008; Kinda 2010; Gauselmann, Knell, Stephan 2011; Amendolagine et al. 2013; Schäffler, Hecht, Moritz 2014].

There is a high probability that such dependence will be valid for Poland, which is characterized by a high level of education and relatively low costs of labor force (including high-skilled workers). There are some approaches to measuring the level of high-skilled workers. Ledyaeva and Linden [2006] considered it as a ratio of the graduated in total population, Pusterla and Resmini [2007] measured this determinant by the number of third level students over total population, Amendolagine et al. [2013] used the ratio of white collars to the total employment for measuring this determinant. In this model the determinant of high-skilled workers is proxied by the number of current directors and managers in each analyzed firm.

6) Age of a firm. Over the last 5 years some research in the sphere of FDI determinants have begun to use in their models such a factor as age of firm [Kinda 2010; Bedi, Mebratie 2011; Cieślik, Michałek, Nasadiuk 2015].

It can be assumed that older firms accumulate more assets and knowledge during their business activities. Thus, the length of firm's existing and its operation on the market can be perceived as a specific advantage, which can have a positive impact on FDI attracting. However, higher age of a firm can also discourage foreign investors. If the administrative personnel of a firm have been working only on the 
domestic market for a lot of years, there is a probability that they may not be able for FDI attracting. Therefore it is also possible to obtain a negative correlation between firm's age and foreign direct investment in the model.

II. Regional determinants

1) Economic potential of region (EPR) in which a firm operates. This variable is measured by regional GDP (weighted by internal distance) including the potential of market in each region. Thus, EPR variable consists of 3 main components: regional GDP, internal distance and market potential of region.

a) Regional GDP

Regional GDP $\left(\mathrm{GDP}_{i}\right)$ is a standard variable which should be included in models which describe FDI determinants and location choice of MNEs. In this model regional GDP is expressed in million zloty as provided by Polish Central Statistical Office. A large number of researchers used regional GDP as a proxy variable for measuring the market size of region or country GDP [Chung, Alcacer 2002; Coughlin, Terza, Arromdee 1991; Braunerhjelm, Svensson 1996; Head, Ries, Swenson 1999].

b) Internal distance

From the theoretical point of view, the expected dependence between distance and FDI is negative as physical distance is assumed to increase several costs (transport, information, monitoring). Although new technologies (both in communication and transport) are changing relative importance of distance, this variable is still fundamental in empirical investigation on FDI determinants.

The internal distance is generally smaller than external. It is associated with greater weight and therefore it is a sensitive parameter for the measures of centrality.

In order to take the "self-potential" into consideration, the internal distance of each region, i.e. $D_{i i}$, has been calculated by Head and Mayer [2004]:

$$
D_{i i}=0.376 \sqrt{A_{i}}=\frac{2}{3} \sqrt{\frac{A_{i}}{\pi}},
$$

where $A_{i}$ denotes the area of region $i$. The model which is presented in this research includes statistic data for all 16 regions of Poland.

c) Market potential of region (in which a firm operates)

Multinational firms have a market horizon which is by definition larger than the region's. In order to capture the true size of the market each foreign firm can serve from being located in region $i$, we consider the index of market potential, as defined by Harris in his seminal paper of 1954, as a proxy for market demand. According to Harris [1954], the market potential of region $i\left(\mathrm{POT}_{i}\right)$ can be calculated as increasing in purchasing power or GDP of all regions $j\left(\mathrm{GDP}_{j}\right)$ and decreasing in distance or transport cost between regions $i$ and $j\left(D_{i j}\right)$. This can be formulated as:

$$
P O T_{i}=\sum_{j}^{15} \frac{G D P_{j}}{D_{i j}}
$$


where GDP represents the size of location $j$ and $D_{i j}$ the distance between $i$ and $j$, measured in kilometers between the capitals of regions.

The full equation of EPR (Economic potential of region in which a firm operates) is:

$$
E P R_{i}=\frac{G D P_{i}}{D_{i i}}+P O T_{i}=\frac{G D P_{i}}{\frac{2}{3} \sqrt{\frac{A_{i}}{\pi}}}+\sum_{j}^{15} \frac{G D P_{j}}{D_{i j}} .
$$

Based on theoretical background it should be noted that the larger the EPR Index, the higher the probability of attracting foreign direct investment.

2) Road and railroad density (in a region in which a firm operates). These determinants are often used by scholars in their models devoted to regional determinants of foreign direct investment. Road and railroad density relates to infrastructure variables. Cieślik [2005a] used road and railroad density in his investigation and stated that the infrastructure variables impacted FDI inflows. In his model variable of road density was statistically significant in all specifications, but the significance of railroad density variable depended on the specification he used.

Boudier-Bensebaa [2005] also used these determinants in his research of FDI regional determinants. He called these variables availability of infrastructures and measured them as road mileage in meters per square mile of county land area. Yavan [2010] in his paper also used a similar approach and measured road network as a ratio of the length of asphalt roads to province's surface area $\left(\mathrm{km} / \mathrm{km}^{2}\right)$. Hilber and Voicu [2010] and Cieślik [2013] in their studies analyzed the determinants of FDI including railroad density (railroad length/county area) and road density (road length/county area). In this model a similar approach to measuring these characteristics will be used.

3) Location of a firm. There is an assumption that the location of a firm could be a determinant of FDI. It is probable that during the process of choice of location a foreign investor pays attention to the locality in which a firm is operating. A lot of researchers in the sphere of regional FDI determinants used such variables as border effect or locational effect in their model: [Cieślik 2005b; 2005c; 2013; Chidlow, Salciuviene, Young 2009] for Poland, [Iwasaki, Suganuma 2005] for Russian Federation, [Spilkova 2007] for the Czech Republic, [Yavan 2010] for Turkey, [Hilber, Voicu 2010] for Romania, [Schäffler, Hecht, Moritz 2014] for Germany and the Czech Republic.

There are a lot of different approaches to the determination of locational and border effects, Cieślik [2005b, 2005c, 2013] for example by dividing all firms into two groups:

1. A firm is situated in a region which borders EU member and candidate countries.

2. A firm is situated in a region which borders EU non-accessing countries. 


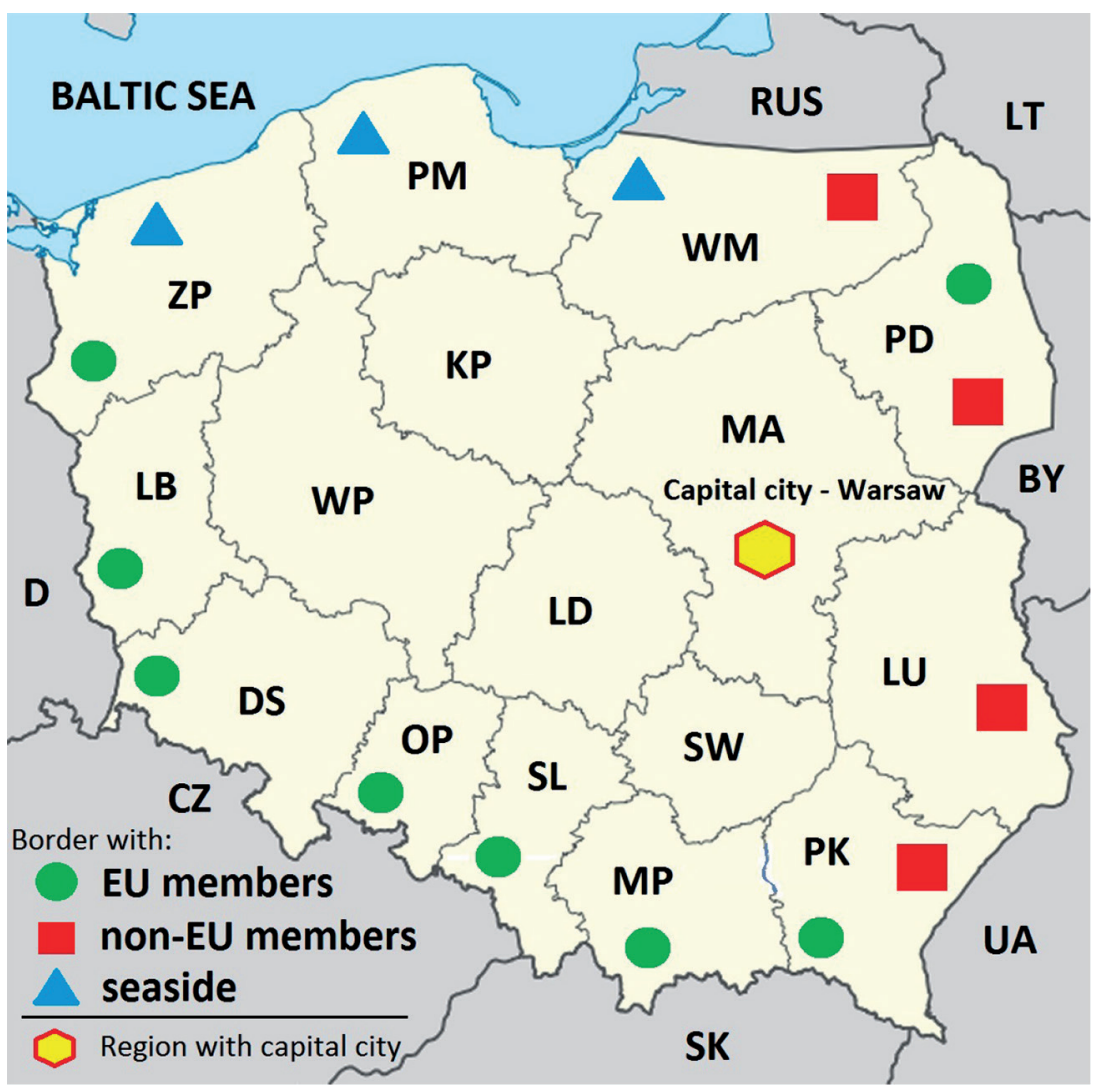

Picture 1. The location of a firm: closer to EU or non-EU countries and closer to seaside or to the capital city - Warsaw

Source: AMADEUS database provided by Bureau van Dijk.

Yavan [2010] also divided all firms into two groups:

1. A firm is situated in a region which has access to a seaport/coast.

2. A firm is situated in a region which has no access to seaport/coast.

Iwasaki and Suganuma [2005], Chidlow, Salciuviene and Young [2009] and Schäffler, Hecht and Moritz [2014] divided all firms into two following groups:

1. Firms which are situated in a region with the capital city of the country.

2. Firms which are not situated in a region with the capital city of the country.

In this model the dummy variable location of a firm represents the combination of the above three approaches and includes such characteristics:

1. A firm is situated in a region which has a common border with EU members.

2. A firm is situated in a region which has a common border with non-EU countries.

3. A firm is situated in a region which has access to the seaside.

4. A firm is situated in a region with the capital city of the country. 


\section{Estimation results}

As it is mentioned above, several models with different methods for the estimation of datasets will be presented in this section. The first method is OLS regression and the results of this model are shown in Table 1. The dependent variable in this model is FDI, the independent variables are described in the table.

Table 1. OLS estimation results

\begin{tabular}{|l|c|c|c|c|}
\hline & All sectors & Manufacture & Sales & Services \\
\hline Total assets & 0.1627 & 0.1196 & 0.1264 & 0.2495 \\
& $(0.0023)$ & $(0.0031)$ & $(0.0033)$ & $(0.0066)$ \\
\hline Productivity & 0.6569 & 0.7659 & 0.6940 & 0.6395 \\
& $(0.0047)$ & $(0.0069)$ & $(0.0068)$ & $(0.0144)$ \\
\hline R\&D & 0.0001 & 0.0001 & 0.0143 & 0.0003 \\
& $(0.0000)$ & $(0.0000)$ & $(0.0008)$ & $(0.0000)$ \\
\hline Firm size & 0.7758 & 0.8349 & 0.7999 & 0.5993 \\
& $(0.0047)$ & $(0.0063)$ & $(0.0065)$ & $(0.0136)$ \\
\hline High-skilled workers & 0.0380 & 0.0223 & 0.0507 & 0.0571 \\
& $(0.0030)$ & $(0.0036)$ & $(0.0055)$ & $(0.0085)$ \\
\hline Age of company & 0.0069 & 0.0077 & 0.0545 & -0.0260 \\
& $(0.0067)$ & $(0.0078)$ & $(0.0110)$ & $(0.0209)$ \\
\hline Economic potential of region & 0.7748 & 0.6888 & 0.6426 & 0.7934 \\
(in which a firm operates) & $(0.0250)$ & $(0.0319)$ & $(0.0346)$ & $(0.0774)$ \\
\hline Road density & -0.2030 & -0.1416 & -0.1371 & -0.1430 \\
& $(0.0194)$ & $(0.0247)$ & $(0.0270)$ & $(0.0610)$ \\
\hline Railroad density & 0.1541 & -0.0795 & -0.3786 & -0.6578 \\
& $(0.1884)$ & $(0.2417)$ & $(0.2576)$ & $(0.6111)$ \\
\hline Location of a company & 0.0031 & 0.0064 & -0.0517 & 0.0995 \\
& $(0.0114)$ & $(0.0141)$ & $(0.0158)$ & $(0.0372)$ \\
\hline Constant & -4.8774 & -4.6186 & -4.2641 & -4.7293 \\
& $(0.1827)$ & $(0.2318)$ & $(0.2507)$ & $(0.5636)$ \\
\hline Number of observations & 218950 & 110640 & 67180 & 41490 \\
\hline R of a model & 0.8023 & 0.8378 & 0.8668 & 0.6896 \\
\hline
\end{tabular}

Source: estimated through STATA using AMADEUS and Polish Central Statistical Office (CSO) databases for the 2003-2012 period. Note: 1) standard errors in parentheses, 2) level of significance: $p<0.05$.

The further stages of estimation strategy were the creation of fixed effects and random effects models followed by Hausman test to determine what model was batter. Hausman test showed that there was no difference between fixed and random effects models in the current analysis. Thus, there will be presented (Table 2) only the results of random effects (GLS) model because fixed effects model shows the same results and there is no need to depict it. 
Table 2. Results of the random effects (GLS) model

\begin{tabular}{|c|c|c|c|c|}
\hline & All sectors & Manufacture & Sales & Services \\
\hline Total assets & $\begin{array}{c}0.0604 \\
(0.0018)\end{array}$ & $\begin{array}{c}0.0413 \\
(0.0024)\end{array}$ & $\begin{array}{c}0.0639 \\
(0.0030)\end{array}$ & $\begin{array}{c}0.1144 \\
(0.0052)\end{array}$ \\
\hline Productivity & $\begin{array}{c}0.6390 \\
(0.0049)\end{array}$ & $\begin{array}{l}0.6601 \\
0.0069\end{array}$ & $\begin{array}{c}0.7089 \\
(0.0077)\end{array}$ & $\begin{array}{c}0.5813 \\
(0.0128)\end{array}$ \\
\hline $\mathrm{R} \& \mathrm{D}$ & $\begin{array}{c}0.0001 \\
(0.0000)\end{array}$ & $\begin{array}{c}0.0001 \\
(0.0000)\end{array}$ & $\begin{array}{l}0.0145 \\
0.0009 \\
\end{array}$ & $\begin{array}{c}0.0002 \\
(0.0000) \\
\end{array}$ \\
\hline Firm size & $\begin{array}{c}0.7831 \\
(0.0056\end{array}$ & $\begin{array}{c}0.8265 \\
(0.0077)\end{array}$ & $\begin{array}{c}0.8220 \\
(0.0083)\end{array}$ & $\begin{array}{c}0.5962 \\
(0.0148) \\
\end{array}$ \\
\hline High-skilled workers & $\begin{array}{c}0.0875 \\
(0.0054) \\
\end{array}$ & $\begin{array}{c}0.0692 \\
(0.0066) \\
\end{array}$ & $\begin{array}{c}0.0748 \\
(0.0092) \\
\end{array}$ & $\begin{array}{c}0.1231 \\
(0.0139) \\
\end{array}$ \\
\hline Age of company & $\begin{array}{c}0.0131 \\
(0.0088) \\
\end{array}$ & $\begin{array}{l}-0.0069 \\
(0.0110) \\
\end{array}$ & $\begin{array}{c}0.0635 \\
(0.0140) \\
\end{array}$ & $\begin{array}{r}0.0258 \\
(0.0255) \\
\end{array}$ \\
\hline $\begin{array}{l}\text { Economic potential of region } \\
\text { (in which a firm operates) }\end{array}$ & $\begin{array}{c}0.7055 \\
(0.0178) \\
\end{array}$ & $\begin{array}{c}0.6788 \\
(0.0231) \\
\end{array}$ & $\begin{array}{c}0.5447 \\
(0.0284) \\
\end{array}$ & $\begin{array}{c}0.8803 \\
(0.0504) \\
\end{array}$ \\
\hline Road density & $\begin{array}{l}-0.1636 \\
(0.0282) \\
\end{array}$ & $\begin{array}{c}-0.1277 \\
(0.0373) \\
\end{array}$ & $\begin{array}{c}-0.0460 \\
(0.0389) \\
\end{array}$ & $\begin{array}{l}-0.2153 \\
(0.0831) \\
\end{array}$ \\
\hline Railroad density & $\begin{array}{l}-0.2900 \\
(0.3000)\end{array}$ & $\begin{array}{l}-0.3417 \\
(0.3960)\end{array}$ & $\begin{array}{l}-0.8710 \\
(0.3970)\end{array}$ & $\begin{array}{c}-0.9043 \\
(0.9049) \\
\end{array}$ \\
\hline Location of a company & $\begin{array}{c}0.0230 \\
(0.0195) \\
\end{array}$ & $\begin{array}{c}0.0369 \\
(0.0250)\end{array}$ & $\begin{array}{l}-0.0521 \\
(0.0256)\end{array}$ & $\begin{array}{c}0.0627 \\
(0.0596)\end{array}$ \\
\hline Constant & $\begin{array}{l}-3.7243 \\
(0.1191)\end{array}$ & $\begin{array}{l}-3.5278 \\
(0.1555) \\
\end{array}$ & $\begin{array}{l}-3.4334 \\
(0.1910)\end{array}$ & $\begin{array}{l}-4.3755 \\
(0.3373) \\
\end{array}$ \\
\hline Number of observations & 219310 & 110640 & 67180 & 41490 \\
\hline $\mathrm{R}^{2}$ of a model & 0.7839 & 0.8230 & 0.8600 & 0.6565 \\
\hline
\end{tabular}

Source: estimated through STATA using AMADEUS and Polish Central Statistical Office (CSO) databases for the 2003-2012 period. Note: 1) standard errors in parentheses, 2) level of significance: $p<0.05$.

It should be noted that all specifications are characterized by the significance of such determinants as total assets, productivity, $R \& D$, firm size, high-skilled workers and the economic potential of a region in which a firm operates. The most significant determinant in the model is firm size, but regarding this matter through the prism of firm's sectoral affiliation it can be found that firm size is the most significant determinant of FDI for manufacturing and sales. The most significant determinant of foreign direct investment for the sector of services is productivity and the second place in the context of significance for this sector belongs to such a determinant as firm size. The second place for manufacturing and sales sectors takes such a determinant as productivity of a firm. These results are confirmed by both OLS and fixed and random effects models.

The following factors in the context of their significance in the model are economic potential of a region in which a firm operates and the total assets of a firm. 
Moreover, for such sectors as sales and services the total assets are more significant than EPR, but for manufacturing the economic potential of a region in which a firm operates is more considerable than the total assets of a firm. Thus, it can be concluded that foreign investors who are going to locate their capital in manufacturing sector of a recipient country pay more attention to the level of economic potential of the region in which a host firm operates than to its assets. Therefore, a foreign investor considers the most the possibility for further growth, not the existing capitalization of the host company.

Such determinants as R\&D and the availability of high-skilled workers are also significant and have a positive impact on the attraction of FDI in Polish firms. It should be mentioned that the availability of high-skilled workers is more significant in such sectors as sales and services. R\&D is more considerable for manufacturing sector which is quite logical.

All estimations showed that age of a firm was significant only for firms of sales sector. Therefore, foreign investors who are going to invest into firms which operate in sales sector pay attention to the history of a host firm and the longer the firm operates in the market, the greater the investors' confidence.

There is one more interesting result that such a determinant as location of a company is positive and statistically significant only for firms of services sector. It should also be noted that for the most specifications such determinants as road and railroad density were not significant.

\section{Conclusions}

One of the most important findings of this study is that firm-level determinants are more influential factors than regional ones in the context of foreign investors' locational choice. Foreign investors pay more attention to micro-level characteristics during the decision making processes regardless of the industry in which a host company operates.

It was found that the most important determinants of FDI were firm size and productivity of a host firm. Moreover, the most significant factor for companies of manufacturing sector was productivity and for firms of such sectors as sales and services the most considerable determinant was firm size. Based on the obtained results it should be concluded that foreign investors who are going to invest in Poland prefer large and very productive firms.

This research shows that the most significant and influential factor among the regional FDI determinants was the economic potential of a region in which a host firm operates. This factor is especially very important for foreign investors who intend to place their productive facilities into the manufacturing sector of Poland. According to the results of the model EPR determinant is more significant than such determinants as R\&D and the availability of high-skilled workers for all sectors of 
Table 3. Distances between the capitals of Polish regions and the regions' area (in $\mathrm{km}^{2}$ )

\begin{tabular}{|c|c|c|c|c|c|c|c|c|c|c|c|c|c|c|c|c|}
\hline & DŚ & KP & ŁD & LU & LB & MP & MA & OP & PK & PD & $\mathrm{PM}$ & ŚL & ŚW & WM & WP & $\mathrm{ZP}$ \\
\hline $\begin{array}{l}\text { DOLNOŚLĄSKIE (DŚ) } \\
\text { Wrocław }\end{array}$ & 19946 & 27500 & 225 & 415 & 266 & 270 & 345 & 85 & 435 & 535 & 485 & 195 & 300 & 475 & 170 & 383 \\
\hline $\begin{array}{l}\text { KUJAWSKO-POMORSKIE (KP) } \\
\text { Bydgoszcz }\end{array}$ & 275 & 17971 & 205 & 420 & 210 & 475 & 255 & 340 & 535 & 400 & 170 & 405 & 345 & 200 & 130 & 255 \\
\hline $\begin{array}{l}\text { ŁÓDZKIE (ŁD) } \\
\text { Łódź }\end{array}$ & 225 & 205 & 18218 & 250 & 361 & 275 & 135 & 200 & 320 & 225 & 340 & 205 & 135 & 275 & 210 & 477 \\
\hline $\begin{array}{l}\text { LUBELSKIE (LU) } \\
\text { Lublin }\end{array}$ & 415 & 420 & 250 & 25122 & 625 & 255 & 170 & 405 & 175 & 255 & 515 & 330 & 180 & 385 & 445 & 741 \\
\hline $\begin{array}{l}\text { LUBUSKIE (LB) } \\
\text { Gorzów Wielkopolski }\end{array}$ & 266 & 210 & 361 & 625 & 13987 & 439 & 474 & 366 & 713 & 533 & 330 & 464 & 507 & 447 & 167 & 112 \\
\hline $\begin{array}{l}\text { MAŁOPOLSKIE (MP) } \\
\text { Kraków }\end{array}$ & 270 & 475 & 275 & 255 & 439 & 15182 & 315 & 185 & 170 & 445 & 610 & 70 & 135 & 530 & 440 & 655 \\
\hline $\begin{array}{l}\text { MAZOWIECKIE (MA) } \\
\text { Warszawa }\end{array}$ & 345 & 255 & 135 & 170 & 474 & 315 & 35558 & 315 & 310 & 195 & 350 & 300 & 175 & 220 & 305 & 585 \\
\hline $\begin{array}{l}\text { OPOLSKIE (OP) } \\
\text { Opole }\end{array}$ & 85 & 340 & 200 & 405 & 366 & 185 & 315 & 9411 & 350 & 505 & 515 & 110 & 230 & 475 & 255 & 482 \\
\hline $\begin{array}{l}\text { PODKARPACKIE (PK) } \\
\text { Rzeszów }\end{array}$ & 435 & 535 & 320 & 175 & 713 & 170 & 310 & 350 & 505 & 515 & 110 & 230 & 475 & 255 & 482 & 831 \\
\hline $\begin{array}{l}\text { PODLASKIE (PD) } \\
\text { Białystok }\end{array}$ & 535 & 400 & 225 & 255 & 533 & 445 & 195 & 505 & 515 & 20187 & 395 & 490 & 365 & 235 & 485 & 771 \\
\hline $\begin{array}{l}\text { POMORSKIE (PM) } \\
\text { Gdańsk }\end{array}$ & 485 & 170 & 340 & 515 & 330 & 610 & 350 & 515 & 110 & 395 & 18310 & 530 & 505 & 160 & 330 & 347 \\
\hline $\begin{array}{l}\text { ŚLĄSKIE (ŚL) } \\
\text { Katowice }\end{array}$ & 195 & 405 & 205 & 330 & 464 & 70 & 300 & 110 & 230 & 490 & 530 & 12333 & 210 & 480 & 360 & 580 \\
\hline $\begin{array}{l}\text { ŚWIĘTOKRZYSKIE (ŚW) } \\
\text { Kielce }\end{array}$ & 300 & 345 & 135 & 180 & 507 & 135 & 175 & 230 & 475 & 365 & 505 & 210 & 11710 & 395 & 330 & 623 \\
\hline $\begin{array}{l}\text { WARMIŃSKO-MAZURSKIE } \\
\text { (WM) Olsztyn }\end{array}$ & 475 & 200 & 275 & 385 & 447 & 530 & 220 & 475 & 255 & 235 & 160 & 480 & 395 & 24173 & 330 & 484 \\
\hline $\begin{array}{l}\text { WIELKOPOLSKIE (WP) } \\
\text { Poznań }\end{array}$ & 170 & 130 & 210 & 445 & 167 & 440 & 305 & 255 & 482 & 485 & 330 & 360 & 330 & 330 & 29826 & 283 \\
\hline $\begin{array}{l}\text { ZACHODNIOPOMORSKIE (ZP) } \\
\text { Szczecin }\end{array}$ & 383 & 255 & 477 & 741 & 112 & 655 & 585 & 482 & 831 & 771 & 347 & 580 & 623 & 484 & 283 & 22892 \\
\hline
\end{tabular}

Source: Polish Central Statistical Office (CSO) in Warsaw. 
Polish economy and in case of manufacturing sector it is more considerable than such a factor as total assets of a host firm.

As it was mentioned above such micro-level characteristics as R\&D and availability of high-skilled workers had impacted FDI inflows into Polish firms, but the significance of these determinants was lower than the significance of such factors as firm size, productivity, economic potential of a region in which a firm operated and the capitalization of a host firm measured by its total assets. This suggests that a lot of foreign investors do not regard Polish firms as knowledge-intensive and the volume of knowledge-seeking FDI into Poland remains at low level compared with other types of FDI. Nowadays Polish firms have no such high technologies that foreign investors consider R\&D as the main and essential factor to attract their FDI.

One more finding of this study is that such a determinant as age of a firm is significant only for the firms of sales sector and the location of a firm is a considerable factor only for the firms of services sector. It should also be mentioned that most specifications showed that such determinants as road and railroad density were insignificant.

On the whole it should be concluded that foreign investors who are going to locate their facilities in Polish manufacturing sector prefer large and productive firms with the sufficient level of $R \& D$ and capitalization which are located in the regions with high level of economic potential. For foreign investors who intend to invest into the firm of Polish services sector an important factor is the location of a host firm and they prefer to invest into firms which are situated closer to the border with EU members, closer to the seaside and into firm which situated in the capital city of Poland - Warsaw. Foreign investors who are going to engage into investment activity within the Polish sales sector prefer older firms (that have been operating on the market for a long time) of medium and large size with the high level of productivity and capitalization.

\section{References}

Amendolagine V., Boly A., Coniglio N.D., Prota F., Seric A., 2013, FDI and local linkages in developing countries: Evidence from Sub-Saharan Africa, World Development, Vol. 50, Issue: C, pp. 41-56.

Barrios S., Strobl E., Gorg H., 2003, Multinationals' location choice, agglomeration economies and public incentives, Nottingham University, Research Papers, 33.

Basile R., Castellani D., Zanfei A., 2008, Location choices of multinational firms in Europe: the role of EU cohesion policy, Journal of International Economics, Elsevier, Vol. 74 (2), pp. 328-340.

Bedi A.S., Mebratie A.D., 2011, Foreign direct investment, black economic empowerment and labour productivity in South Africa, IZA Institute for the Study of Labor, Discussion Paper No. 6048.

Bénassy-Quéré A., Coupet M., Mayer T., 2005, Institutional determinants of foreign direct investment, CEPII, Working Paper, No. 2005-05.

Bevan A., Estrin S., 2000, The Determinants of foreign direct investment in transition economies, Discussion Paper, No. 9, Center for New and Emerging Market, London Business School, London. 
Biswas R., 2002, Determinants of foreign direct investment, Review of Development Economics, Vol. 6, No. 3, pp. 492-504.

Blomstrom M., Lipsey R.E., 1991, Firm size and foreign operation of multinationals, The Scandinavian Journal of Economics, Vol. 93, pp. 101-107.

Boudier-Bensebaa F., 2005, Agglomeration economies and location choice: foreign investment in Hungary, Economics of Transition, Vol. 13, pp. 605-629.

Braunerhjelm P., Svensson R., 1996, Host country characteristics and agglomeration in foreign direct investment, Journal of Applied Economics, Vol. 28, pp. 833-840.

Broadman H., Recanatini F., 2001, Where has all the foreign investment gone in Russia?, Policy Research Working Paper, No. 2640, World Bank, Washington D.C.

Cantwell J.A., 1989, Technological Innovations and Multinational Corporations, London, Basil Blackwell.

Cantwell J.A., Janne O., 1999, Technological globalisation and innovation centers: the role of corporate technological leadership and locational hierarchy, Research Policy, Vol. 28 (2-3), pp. 119-144.

Cantwell J.A., Piscitello L., 2002, The location of technical activities of MNCs in European regions: the role of spillovers and local competencies, Journal of International Management, Vol. 8, p. 69-96.

Cantwell J.A., Piscitello L., 2005, Recent Location of Foreign-owned Research and Development Activities by Large Multinational Corporations in the European Regions: The Role of Spillovers and Externalities, Regional Studies, Taylor \& Francis Journals, Vol. 39 (1), p. 1-16.

Carstensen K., Toubal F., 2004, Foreign direct investment in Central and Eastern European countries: a dynamic panel analysis, Journal of Comparative Economics, Vol. 32, No. 1, pp. 3-22.

Caves R.E., 1974, Multinational firms, competition, and productivity in host-country markets, Economica, Vol. 41, pp. 176-193.

Chidlow A., Salciuviene L., Young S., 2009, Regional determinants of inward FDI distribution in Poland, International Business Review, Vol. 18/2, pp. 119-33.

Chung W., Alcacer J., 2002, Knowledge seeking and location choice of foreign investment in the United States, Management Science, Vol. 48/12, pp. 1535-1554.

Cieślik A., 2005a, Regional characteristics and the location of foreign firms within Poland, The Journal of Applied Economics, Vol. 37, pp. 863-874.

Cieślik A., 2005b, The location of foreign firms and national border effects: the case of Poland, Tijdschrift Voor Economische en Sociale Geografie, Vol. 96, pp. 287-297.

Cieślik A., 2005c, European integration, national border effects and the location of multinational enterprises in Poland: the case of new voivodships, Brussels Economic Review - Cahiers Economiques de Bruxelles, Vol. 48, pp. 1-13.

Cieślik A., 2013, Determinants of the location of foreign firms in Polish regions: does firm size matter?, Tijdschrift voor Economische en Sociale Geografie, Royal Dutch Geographical Society KNAG, Vol. 104 (2), pp. 175-193.

Cieślik A., Michałek J., Nasadiuk I., 2015, Determinants of export performance of Ukrainian firms, Institute of Economic Research Working Papers, No. 41/2015.

Greene W.H., 2008, Econometric Analysis, Prentice Hall, Upper Saddle River.

Coughlin C., Terza J., Arromdee V., 1991, State characteristics and the location of foreign direct investment within the United States, The Review of Economics and Statistics, Vol. 73, pp. 675-683.

Deichmann J.I., 2002, The spatial distribution of foreign direct investment in Poland, An Integrated Methodology, Current Politics and Economics of Russia, Eastern and Central Europe, Vol. 17 (2), pp. 193-206.

Demirhan E., Masca M., 2008, Determinants of foreign direct investments flows to developing countries: a cross-sectional analysis, Prague Economic Papers, Vol. 2008, No. 4, pp. 356-369.

Disdier A.C., Mayer Y., 2004, How different is Eastern Europe? Structure and determinants of locational choices by French firms in Eastern and Western Europe, Journal of Comparative Economics, Vol. 32, No. 2, pp. 280-96. 
Djankov S., Hoekman B., 2000, Foreign investment and productivity growth in Czech enterprises, World Bank Economic Review, Vol. 14(1), pp. 49-64.

Domański B., 2001, Poland: Labour and the Relocation of Manufacturing from the EU, [in:] CEE Countries in EU Companies 'Strategies of Industrial Restructuring and Relocation, ed. G. Gradev, European Trade Union Institute, Brussels, pp. 21-49.

Domański B., 2004, Local and regional embeddedness of foreign industrial investors in Poland, Prace Geograficzne, Vol. 114, pp. 37-54.

Dunning J.H., 1988, The eclectic paradigm of international production: a restatement and some possible extensions, Journal of International Business Studies, Vol. 19, No. 1.

Garibaldi P., Mora N., Sahay R., Zettelmeyer J., 2001, What moves capital to transition economies?, IMF Staff Papers, Vol. 48, special issue.

Gauselmann A., Marek P., 2012, Regional determinants of MNE's location choice in post-transition economies, Empirica, Springer, Vol. 39 (4), November, pp. 487-511.

Gauselmann A., Knell M., Stephan J., 2011, What drives FDI into Central East Europe? Evidence from the IWH-FDI-Micro Database, Post-Communist Economies, Vol. 23/3, pp. 343-58.

Ghemawat P., Kennedy R.E., 1999, Competitive shocks and industrial structure: the case of Polish manufacturing, International Journal of Industrial Organization, Vol. 17, pp. 847-867.

Görg H., Mühlen H., Nunnenkamp P., 2010a, Firm heterogeneity, industry characteristics and types of FDI: the case of German FDI in the Czech Republic, Aussenwirtschaft, Vol. 46 (8), pp. 1367-1384.

Görg H., Mühlen H., Nunnenkamp P., 2010b, FDI liberalization, firm heterogeneity and foreign ownership: German firm decisions in reforming India, Journal of Development Studies, Vol. 65 (3), pp. 271-295.

Hagemejer J., Tyrowicz J., 2012, Is the effect really so large? Firm-level evidence on the role of FDI in a transition economy, The Economics of Transition, The European Bank for Reconstruction and Development, Vol. 20 (2), pp. 195-233.

Harris C.D., 1954, The market as a factor in the localization of industry in the United States, Annals of the Association of American Geographers, Vol. 44, pp. 315-348.

Head C., Ries J., Swenson D., 1999, Attracting foreign manufacturing: investment promotion and agglomeration, Regional Science and Urban Economics, Vol. 29, pp. 197-218.

Head K., Mayer T., 2004, Market potential and the location of Japanese investment in the European Union, Review of Economics and Statistics, Vol. 86(4), pp. 959-972.

Hilber C.A.L., Voicu I., 2010, Agglomeration economies and the location of foreign direct investment: empirical evidence from Romania, Regional Studies, Vol. 44, pp. 355-371.

Hong E., Li T., Sun L., 2007, Location of foreign direct investment in China: a spatial dynamic panel data analysis by country of origin, DeFiMS Discussion Paper.

Horst T., 1972, Firm and industry determinants of the decision to invest abroad: an empirical study, The Review of Economics and Statistics, Vol. 54, pp. 258-266.

Iwasaki I., Suganuma K., 2005, Regional distribution of foreign direct investment in Russia, PostCommunist Economies, Vol. 17 (2), pp. 153-172.

Kasuga H., 2007, Evaluating the impacts of foreign direct investment, aid and saving in developing countries, Journal of International Money and Finance, Elsevier, Vol. 26 (2), pp. 213-228.

Kinda T., 2010, Investment climate and FDI in developing countries: firm-level evidence, World Development, Elsevier, Vol. 38 (4), April, pp. 498-513.

Kinoshita Y., Campos N.F., 2003, Why does FDI go where it goes? New evidence from the transition economies, CEPR Discussion Paper, No. 3984, CEPR, London.

Klimek A., 2009, The Determinants of Outward Foreign Direct Investment: The Case of Poland, Wroclaw University of Economics, Wroclaw.

Konings J., 2001, The effects of foreign direct investment on domestic firms: evidence from firm-level panel ata in emerging economies, Economics of Transition, Vol. 9(3), pp. 619-33. 
Ledyaeva S., Linden M., 2006, Testing for FDI gravity model in Russian regions, Working Paper No. 32/06, Department of Business and Economics, University of Joensuu.

Lin H., Yeh R.S., 2003, The interdependence between FDI and R\&D: an application of an endogenous switching model to Taiwan's electronics industry, Applied Economics, Vol. 37, issue 15, pp. 1789-1799 .

Liu W.-H., Nunnenkamp P., 2011, Domestic repercussions of different types of FDI: firm-level evidence for Taiwanese manufacturing, World Development, Elsevier, Vol. 39 (5), May, pp. 808-823.

Luo Z., 2013, Mechanism Design for Sustainability Techniques and Cases, E-Business Technology Institute, The University of Hong Kong, Springer Science + Business Media, Dordrecht.

Nelson R.R., Phelps E.S., 1966, Investment in humans, technological diffusion, and economic growth, American Economic Review, Vol. 56 (2), pp. 69-75.

Przybylska K., Malina A., 2000, The determinants of foreign direct investment in transforming economies: empirical evidence from Poland, Statistics in Transition, Vol. 4 (5), pp. 883-899.

Pusterla F., Resmini L., 2007, Where do foreign firms locate in transition countries? An empirical investigation, The Annals of Regional Science, Vol. 41 (4), pp. 835-856.

Raff H., Ryan M.J., 2008, Firm-specific characteristics and the timing of foreign direct investment projects, Review of World Economics, Springer, Vol. 144 (1), April, pp. 1-31.

Resmini L., 1999, The determinants of foreign direct investment into the CEECs: new evidence from sectoral patterns, LICOS Discussion Paper 83, LICOS, Centre for Transition Economies, Leuven.

Schäffler J., Hecht V., Moritz M., 2014, Regional determinants of German FDI in the Czech Republic: evidence from a gravity model approach, IAB Discussion Paper 201403, Institute for Employment Research, Nuremberg.

Schneider F., Frey B.S., 1985, Economic and political determinants of foreign direct investment, World Development, Elsevier, Vol. 13 (2), February, pp. 161-175.

Spilkova J., 2007, Foreign firms and the perception of regions in the Czech Republic: a statistical examination, Tijdschrift voor Economische en Sociale Geografie, Vol. 98 (2), pp. 260-275.

Torres-Reyna O., 2007, Panel data analysis fixed and random effects, Data and Statistical services, Princeton University, Princeton.

Wang P., Alba J.D., Park D., 2013, Determinants of different modes of FDI: firm-level evidence from Japanese FDI into the US, Open Economies Review, Vol. 24 (3), July 1, pp. 425-446.

Xu X., Sheng Y., 2012, Productivity spillovers from foreign direct investment: firm-level evidence from China, World Development, Vol. 40, No. 1, pp. 62-74.

Yavan N., 2010, The location choice of foreign direct investment within Turkey: an empirical analysis, European Planning Studies, Vol. 18, pp. 1675-1705. 